\title{
$\mathrm{ODA}$ 확대에 관한 $\mathrm{OECD} / \mathrm{WB}$ 합동회의 결과 및 개발원조위원회 정기회의 결과
}

$6.27 \mathrm{ODA}$ 확대에 관한 $\mathrm{OECD} / \mathrm{WB}$ 합동회의 및 6.28 개발원조위원회 정기회의가 개최된 바, 주요 결과 아래 보고함.

\section{I. 핵심요지}

\section{ODA 확대에 관한 $\mathrm{OECD/WB}$ 합동회의} (6.27) 결과

- DAC 사무국은 회원국의 향후 3 년간의 수원 국가별 $\mathrm{ODA}$ 지출계획을 조사하고 동 결과 를 발표함. 동 조사 실시 배경은 향후 공여국 의 $\mathrm{ODA}$ 총액이 늘어날 전망임에 따라, 개별 수원국별로 지원받을 ODA규모를 파악하여 수원국의 빈곤퇴치계획 수립에 기여하고자 하는 것임.

- 아프리카에 대한 원조를 두배로 늘리겠다 (doubling)는 국제사회의 공약이 아직 구
체적인 지출계획으로까지 발전되지 못하

였으며, 따라서 아프리카에 대한 원조규모 증가는 2009년 또는 2010년에 이루어질 전망

- 금번 조사는 $\mathrm{DAC}$ 회원국 및 5 개 국제기구 (WB, EC, UNDP, UNICEF, IMF)에 대하여 실시하였으나, 미국, 이태리 등 다수 G7 국 가들이 참여하지 않아 조사결과의 신뢰도가 크게 떨어짐(총 $\mathrm{ODA}$ 흐름의 약 $27 \%$ 를 가지 고 분석한 결과).

- 미국은 현재 $\mathrm{ODA}$ 개혁작업을 진행중이라 조사에 참여할 수 없었다고 밝힘.

- 금번 조사에 참여한 국가들도 $\triangle$ 긴급원조, 난민지원, 부채탕감 등 상당수 ODA 사업은 미래의 배정계획을 미리 수립하기 어렵고, $\triangle$ 특정국가에 대한 지출계획 외에 국가를 특 정하지 않은 배정(global allocation)이 있으 며, $\triangle$ 국내예산규정상 미래의 지출계획 수립 이 어렵다는 등의 이유로 정확한 forward 
data를 제출하기 어려운 부분이 많다는 점을 언급하면서 조사방법론의 개선을 촉구함.

- 독일, 캐나다 등 다수 국가들은 $\triangle$ 미래의 지 출계획 파악은 수원국의 계획수립뿐만 아니 라 공여국간 원조조정 및 원조계획 수립에도 매우 유용할 것이고, $\triangle$ 현재로서는 정확한 정보제공이 어렵다 하더라도 앞으로 공여국 의 행태변화를 촉구하는 수단이 될 수 있음 을 언급하면서 앞으로도 미래의 지출계획조 사 작업을 계속할 것을 촉구함.

\section{2. 개발원조위원회 정기회의(6.28) 결과}

- Non-DAC 공여국과의 정책협력관련, 우리 나라를 포함하여 $\mathrm{OECD}$ 회원국이면서 $\mathrm{DAC}$ 비회원국으로 남아있는 8 개국은 현재 모든 $\mathrm{DAC}$ 회의에 참여하고 있고, 이들 국가의 $\mathrm{DAC}$ 가입을 지원하기 위해, 동 국가들을 여 타 Non-DAC 공여국으로부터 구별하여 추 진하기로 함.

- 우선 동 국가들을 "OECD member DAC observers"라 명명하고, 동 국가에 대한 협 력은 outreach라는 용어 대신에 inreach라 는 용어를 사용하며, 동 국가에 대한 정책협 력을 아래와 같이 추진

- 매년 12 월 SLM 회의 직전에 DAC 의장과 의 비공식대화 개최

- 금년 10.12 13간 터키 이스탄불에서 DAC 회원국과 OECD member DAC observers
대표들이 함께 참석하는 정책대화 개최 (DAC 가입 준비를 위한 사전 정책대화 프 로세스, 원조효과 아젠다, 통계 등을 다루 기로 합의)

- 한편, 첵크는 $\mathrm{DAC}$ 가입 준비 차원에서 새로 운 개발협력법 제정을 추진하고, 자국의 $\mathrm{ODA}$ 에 대한 $\mathrm{DAC}$ 의 light peer review를 받 기를 희망함.

- 대다수 회원국들이 지지 표명. 다만, 소요 비용은 첵크 정부가 부담

- 여타 Non-DAC 공여국은 BRIC s, 아랍공여 국, Non-OECD EU 회원국으로 구분하여 그룹별로, 국가별로 상이한 접근을 추진하고 원조효과 개선에 중점을 두며 점진적 협력 강화를 추진하기로 하였음.

\section{3. 관찰 및 건의사항}

- 우리나라는 아직 DAC 비회원국으로서 금 번 향후 3 년간의 $\mathrm{ODA}$ 지출계획 조사대상 에서 배제되었지만, 우리의 ODA 선진화를 위해 현재의 1 년 단위 사업계획 외에 3 년 단위 사업계획 수립을 검토할 필요가 있다 고 사료됨.

- Non-DAC 공여국과 DAC 회원국과의 정책 대화를 위한 이스탄불 회의(10.12-13)는 $\mathrm{DAC}$ 회원국과 $\mathrm{OECD}$ 내 $\mathrm{DAC}$ 비회원국간에 최초로 개최되는 정책대화임을 감안, 동 회 의에 본부대표단의 참석을 건의함. 


\section{II. 상세 논의내용}

\section{1. 제3차 $\mathrm{ODA}$ 확대에 관한 $\mathrm{OECD/WB}$ 합동회의(6.27)}

- DAC 사무국은 회원국의 향후 3 년간의 수원 국가별 $\mathrm{ODA}$ 지출계획, 취약국가에 대한 정 책, 분야별 우선순위, 다자간 원조 및 양자간 원조간의 배분, 중점지원국에 관한 사항을 조사하고 동 결과를 발표함. 동 조사를 실시 하게 된 배경은 그간 다수 공여국이 ODA 확 대를 공약함에 따라 $\mathrm{ODA}$ 총액이 늘어날 전 망이지만, 개별 수원국별로 지원받을 ODA 규모를 파악하지 못할 경우, 수원국의 빈곤 퇴치계획 수립이 어렵고, 그만큼 원조효과가 줄어든다는 인식에 따라 원조효과 증진차원 에서 추진하였음.

- 이번 조사결과 파악된 주요사항은 다음과 같 음(상세 $\mathrm{DCD} / \mathrm{RD}$ (2006)2/RD4 참조)

- 아프리카에 대한 원조를 두배로 늘리겠다 (doubling)는 국제사회의 공약이 아직 구 체적인 지출계획으로까지 발전되지 못하 였으며, 따라서 아프리카에 대한 원조규모 증가는 2009년이나 2010년에 이루어질 전망

- 2004년도에 5억불 이상의 원조를 받았던 상위 16 개국 중 탄자니아, 베트남, 파키스 탄, 모잠비크, 우간다, 수단, 케냐, 말라위 및 루안다는 향후 3 년간 $20 \%$ 내지 $25 \%$ 의
수원액이 증가될 것으로 전망

- 인도, 방글라데시, 나이지리아, PNG 및 부르키나파소는 정체상태로 예상되며, 이 디오피아와 스리랑카는 각각 $13 \%$ 감소할 것으로 전망. 또한, 네팔, 아이티, 동티모 르는 20 내지 $25 \%$ 의 감소가 예상됨.

- 과테말라, 모로코, 터키, 엘살바돌, 알제리 아, 도미니카공, 쿠바, 소말리아, 멕시코, 아르헨티나, 튀니지아 11개국은 2008년까 지 원조가 두배이상 늘어날 것으로 예상됨. - 아프리카 국가중 9 개국만이(탄자니아, 모 잠비크, 우간다, 이디오피아, 수단, 케나, 잠비아, 말라위, 앙골라) 5 천만불 이상 증 가될 것으로 보임.

- 베트남과 볼리비아는 공여국들이 선호하 는 수원국(donor darlings)으로서 앞으로 도 원조규모가 계속 증가할 전망

- 동 조사작업은 22 개 $\mathrm{DAC}$ 회원국 및 5 개 구 제기구(WB, EC, UNDP, UNICEF, IMF)에 대하여 실시하였으나, 미국, 이태리 등 다수 G7 국가들이 조사에 응하지 않았고, 16 개국 만이 향후 3 년간의 지출계획을 밝힘에 따라 조사결과의 신뢰도가 크게 떨어졌음.

- 총 ODA 흐름의 약 $27 \%$ 만 가지고 분석을 실시함.

- 미국은 현재 국내에서 ODA 개혁작업이 진 행중이기 때문에 조사에 참여하지 못했다고 설명하고, 전체 $\mathrm{ODA}$ 의 4 분의 1 의 흐름을 가 지고 분석한 결론은 사실을 오도할 위험성이 
있다고 언급하고 금번 조사 결과에 큰 의미 를 부여하지 말아야 한다고 주장함.

- 네덜란드, 노르웨이, 오지리 등 다수 국가들 은 국가별 배분과 global allocation을 명확 하게 구분하기 어려운 점, 인도적 지원, 긴급 원조, 난민지원, 부채탕감 등 forward data 를 제출하기 어려운 부분이 많았다는 점을 언급하고, 실제 자국 총 $\mathrm{ODA}$ 의 약 $25 \%$ 만 커 버되었기 때문에 조사에 답변하는데 어려움 이 많았다는 점을 언급하고, 조사의 방법론 의 개선을 촉구함.

- 일본은 예측가능성 제고 차원에서 조사의 중 요성을 인정하지만, 공여국내 예산관련 규정 상 정확한 자료 제출에 한계가 있으며, 현재 시험적으로 다년간 지원계획 수립을 추진중 이라고 소개함.

- 그러나, 독일, 캐나다 등 다수국가는 동 작업 결과가 수원국의 빈곤퇴치계획 수립에 유용 할 뿐만 아니라 공여국의 지원계획수립 및 공여국간 원조조화 추진에도 매우 유용할 것 이며, 당장은 정보제공이 어렵더라도 앞으로 공여국의 행태변화를 촉구하는 수단이 될 수 있음을 언급하면서 앞으로도 동 작업을 계속 할 것을 촉구함.

\section{2. $\mathrm{DAC}$ 정기회의(6.28)}

\section{가. Non-DAC 공여국과의 정책협력}

- 우리나라를 포함하여 $\mathrm{OECD}$ 회원국이면서
$\mathrm{DAC}$ 비회원국으로 남아있는 8개국은 현재 모 든 $\mathrm{DAC}$ 회의에 참여하고 있고, 이들 국가의 $\mathrm{DAC}$ 가입을 지원하기 위해, 동 국가들을 여타 Non-DAC 공여국으로부터 분명하게 구분하 기로 함.

- 우선 동 국가들을 "OECD member DAC observers"라 명명하고, 동 국가에 대한 협력 은 outreach라는 용어 대신에 inreach라는 용어를 사용하며, 동 국가에 대한 정책협력을 아래와 같이 추진하기로 함.

- 매년 12 월 SLM 회의 직전에 DAC 의장과의 비공식대화

- 금년 10.12-13간 터키 이스탄불에서 DAC 회원국과 $\mathrm{OECD}$ member DAC observers 대표들이 함께 참석하는 정책대화를 개최 하고 동 정책대화에서 아래 이슈를 다루기 로 함.

- DAC 가입 준비를 위한 사전 정책대화 프 로세스

- 원조효과 아젠다

- 통계와 보고

- 기술협력

- 체제전환국 및 신흥경제국가에 대한 원조

- institution building

- 첵크는 추후 $\mathrm{DAC}$ 가입을 준비한다는 차원에 서 새로운 개발협력법 제정을 준비하는 것 외 에 자국의 $\mathrm{ODA}$ 에 대한 $\mathrm{DAC}$ 의 light peer review를 받기를 희망한 바, 대다수 회원국들 이 지지입장을 표명하였음. 다만, peer 
review를 받는데 소요되는 비용은 2007-8년 도 예산안이 사실상 확정되어 있음을 감안, 첵 크 정부가 부담하기로 하였음.

- 여타 Non-DAC 공여국은 BRIC's, 아랍공여 국, Non-OECD EU 회원국으로 구분하여 그 룹별로, 국가별로 상이한 접근을 추진하며 원 조효과 개선에 중점을 두고 점진적으로 협력 을 강화하기로 하였음.

\section{나. PARIS21 성과평가 결과 및 향후방향}

- PARIS21이 최근 실시한 성과평가 결과 및 향 후방향에 관한 보고서를 검토하고 이를 승인 한 바, 주요 내용은 아래와 같음.

- PARIS21에 대하여 독립적인 검토그룹이 실시한 성과평가 결과에 의하면, PARIS21 의 NSDS(National Strategy on Development Statistics) 사업이 성공적이 었고, PARIS21의 제반 활동 및 사업계획이 적절하였다고 평가하면서, 향후 mandate 를 새로이 준비토록 권고

- 따라서 PARIS21 운영그룹은 PARIS21을 2006년 이후에도 계속 존치키로 하고, 사 무국에 새로운 방향을 제시할 것을 요청하 였으며, PARIS21의 향후 주요 업무영역을 개발통계활동의 중요성에 대한 홍보 (advocacy), 전략이행지원, 개도국의 활동 및 공여국 원조활동 조정, 통계 기술지원 등 으로 규정.

- PARIS21과 $\mathrm{OECD}$ 의 관계를 공식적으로 설
정하기로 하고, 이를 위해 2006년 여름부 터 2007년까지 합의서 준비 및 승인에 관한 일정을 제시

- DAC는 PARIS21의 활동 및 향후계획에 대하 여 전폭적인 지지입장을 표명하면서, 통계에 관한 가이드라인 개발, 개도국내 능력개발, 그 간 수립된 전략의 이행 등을 주문하였음.

※ PARIS21(the Partnership in Statistics for Development in the 21st Century)은 1999 년 UN 결의에 따라 개도국에서 개발 관련 통계의 신뢰도를 높여 정책결정 및 모 니터링을 지원하기 위해 설립되었으며, 각 국 정부, 국제기구 대표 및 전문가로 구성 된 컨소시엄으로서 개도국 및 공여국 대표, 국제기구 대표들이 참가하는 운영위원회 를 두고 있으며, $\mathrm{OECD}$ 개발협력국이 사무 국 역할을 하고 있음.

\section{다. $\mathrm{DAC}$ 과 시민단체(CSO)와의 관계}

- $\mathrm{DAC}$ 과 시민단체와의 관계에 대한 사무국 페 이퍼를 검토한 바, 일부 국가들이 시민단체와 의 관계강화 필요성을 언급하였으나, 대다수 참가자들은 주로 아래와 같이 대체로 유보적 의견들을 제시하였음.

- 시민단체의 참여시 유익한 input이 있을 것으로 예상되므로 원칙적으로 이를 환영 하나, 예산 및 행정적 부담 측면을 고려해 야함.

- 현재 주요 회의 계기에 DAC 의장이 시민단 
체와의 개별적 대화채널을 유지하고 있고, 작업반 차원에서 시민단체들의 참여가 가 능하므로 현재의 시스템으로도 시민단체들 의 요구를 충분히 만족시켜 줄 수 있음.

- 시민단체들이 DAC 본회의에 한번 참가하 게 되면 이것이 선례가 되어 앞으로 계속해 야 하는 부담이 있으며, 시민단체들의 요구 는 강하고 집요하기 때문에 수용하는데 어 려움이 따른다는 점을 염두에 두고 신중한 접근이 필요함.

- 시민단체와 민간기업과는 구별해서 대처해 야함.

- 다만, Bill Gates 재단과 같이 대규모 개발원 조재단과의 협조문제는 $\mathrm{DAC}$ 차원에서 유익하 며, 개도국의 지속가능한 발전 및 개도국의 의료보건, 농업 등 공통관심사에 대한 합동회 의 등을 검토할 가치가 있다는데 의견의 일치 를 보았음.

\section{라. DAC 산하기구 통폐합}

- DAC의 2007-08년도 사업 및 예산계획을 검 토하는 과정에서 $\mathrm{DAC}$ 이 너무 많은 일을 하고 있다는 공감대가 형성되었고, DAC 산하기구 의 통폐합을 검토하기로 함에 따라 사무국 페 이퍼를 중심으로 brainstorming 기회를 가 졌음.

- 일본 등 다수 국가들은 현 체제에서 약간의 통폐합을 실시하는 방안을 선호하는 반면에, 미국 등 일부 국가들은 대대적인 통폐합을 선
호한다는 입장을 표명하였음.

- DAC 본회의에서 Peer Review, 커뮤니케이 션, Non-DAC 공여국과의 협력, 정책일관성, 원조 언타잉 등을 직접 다루고, POVNET에 서 투자문제를 함께 다루며, 분쟁방지(CPDC) 와 취약국가그룹을 통합하는데 대해서는 대 체적으로 의견의 일치를 보였음.

- 다만, 무역을 위한 원조(Aid for Trade)를 별 도의 그룹으로 신설할 것인지 또는 현재와 같 이 ad-hoc basis로 운영할 것인지에 대하여 의견이 엇갈렸으며, 원조규모 확대 및 원조체 제를 별도의 그룹으로 신설하는 방안에 대하 여 독일 등이 지지입장을 표명하였음.

- 또한 산하기구 회의에 국제기구 및 개도국 대 표를 참가시키는 문제에 대하여 추가협의를 통해 의견을 모으기로 하였음.

\section{마. 자발적기여금 관리계좌}

- 과거에 회원국이 자발적기여금을 제공할 때 마다 별도의 합의서 및 별도의 계좌를 신설하 여 관리함으로써 사무국의 행정적 부담이 너 무 많았던 문제점을 해결하기 위해 $\mathrm{DAC}$ 은 그간 자발적 기여금 관리 개선방안을 모색해 왔음.

- 이에 따라 사무국은 자발적 기여금 관리계좌 를 18 개로 통합하여 제시하였으나, informal group에서 사전협의를 통해 통폐합을 더욱 강화하여 10 개로 할 것을 제안했고 일본을 제 외한 모든 회원국들이 동의하였음. 
- 일본은 informal group 회의에 참석하지 못한 사정을 설명하고, 일부 계좌의 통합은 이해하나, 우선순위가 높은 사업(예를 들어 non-DAC 공여국과의 대화)을 다른 사업과 통합하는 것은 비합리적이며, 당초의 합의 사항에 위배됨을 들어 유보입장을 굽히지 않았음.
- 결국 의장은 일부 국가들이 계좌를 더 줄여야 한다고 주장하고 있으나, 그나마 10 개로 하여 여타 모든 국가들이 타협하였음을 설명하고, 일본만이 유일하게 반대한다는 점을 지적하 면서 본국 정부와 협의해줄 것을 요청하였음.

[자료: 주오이시디대사관] 